United Kingdom should be encouraged to visit the Colonial medical schools en route. Dr. E. G. Malherbe, principal, Natal University College, stressed the dangers of mass literacy campaigns and elementary education in Africa in exposing the peoples to irresponsible propaganda and to some of the lessdesirable features of Western civilization if they were not accompanied by the parallel process of providing the enlightened leadership and critical interpretation which the Colonial university institutions would give.

Dr. J. W. Davidson (Wellington University College, New Zealand) directed attention to the danger of importing into the Colonies European standards and conceptions of university education insufficiently adapted to the conditions and interests of the local communities, and thus losing deeply rooted popular support for the new colleges. Prof. A. R. Humphreys, of Leicester, suggested that a practical step to remove one of the deterrents to recruitment, namely, fear that it would be difficult to return to home university posts, would be the prompt and systematic notification of appropriate vacancies to staffs serving overseas.

Principal H. J. Page described the activities of the Imperial College of Tropical Agriculture, Trinidad, the primary task of which is postgraduate training in tropical agriculture of students entering the Colonial agricultural services; a secondary function has been training students, chiefly from the West Indies, for a local diploma. The College hopes soon to co-operate with the University College of the West Indies in providing teaching for the London degree in agriculture. Mr. Bernard Williams, dean of the Medical School, described the plans for opening the Faculty of Medicine of the University College of the West Indies in October, the special problems created by the scattered territories of the West Indian Colonies, the assistance which the College had received not only from the Inter-University Council and University of London, but also from McGill University, and the methods by which it was hoped to overcome the technical difficulties in the secondment of clinical teachers.

Prof. W. E. Dyer, principal of Raffles College, Singapore, stressed the importance of the secondment of university teachers to the Colonial colleges as a means of reducing the isolation and fear of loss of academic status of the local staffs. Prof. F. L. Warren, Natal University College, considered that one reason why a greater number of French than British scholars had remained in service in Egypt was that staff seconded there from the Sorbonne or University of Paris were granted in two years the seniority which would accrue from three years service in France; he suggested that the overseas institutions would attract visiting specialists if they made it known that they could offer working facilities and cheap residential accommodation, such as were provided for visiting astronomers and marine biologists in Egypt.

Prof. Lillian Penson, of the University of London, in concluding the discussion, stated that every effort was made, through full consultation with local opinion and by other means, to harness the sympathy and support of the peoples to their university colleges, and that, far from any forcing of standards by the University of London or the Inter-University Council on the local communities, the demand for the highest standards and nothing less came from the peoples themselves. Secondment on temporary service to the Colonial colleges gave an opportunity of attractive work ; from her knowledge of the quality of Sudanese students, she felt confident that staff need have no fear of lowering standards; and the risk of isolation or of being lost sight of was greatly diminished by the work of the Inter-University Council, particularly by its regular visits.

\section{ROCKEFELLER INSTITUTE FOR MEDICAL RESEARCH, PRINCETON}

\author{
By DR. J. A. V. BUTLER
}

$\mathrm{M}$ ANY scientific workers will have heard, with regret and possibly incredulity, of the impending closing of the Princeton Laboratories of the Rockefeller Institute for Medical Research. The decision to close these Laboratories and to concentrate the work of the Institute in New York was reached in the spring of 1947 . The Laboratories are to be closed by 1951; but if an acceptable offer for the site and plant is received before then it will be accepted. Any members of the staff who wish to do so may continue their work in the New York Laboratories.

It would be impertinent to question the reasons which have led to this decision; but friends of the Laboratory, as well as many who have been privileged to receive its hospitality, will be distressed that it should be necessary. The founding of the Princeton Laboratories was a logical consequence of the policy of the Rockefeller Trustees to provide facilities for the study of disease in all its manifestations, in animals and plants as well as in human beings. This policy was magnificently justified by the results achieved, and to an onlooker it seems a grievous and deplorable loss to science that it should be found necessary to reverse it.

The Rockefeller Institute began its work in a temporary building under Dr. Simon Flexner in 1904. The present New York buildings on a site overlooking the East River were begun in 1906 and have provided both a hospital for the study of special diseases and a wide range of laboratories covering all branches of biochemistry and physiology.

The policy of the Trustees to study disease in all its forms led to the establishment in 1914 of the Department of Animal Pathology with laboratories on a country site near Princeton, under Dr. Theobald Smith, who was succeeded in 1930 by Dr. Carl Ten Broeck. In 1931 the plan to provide, in one organisation, for the study of disease as it occurs in all the main orders of living things was completed by the addition to the Princeton establishment of a Laboratory of Plant Pathology. The Princeton Laboratories also housed a Laboratory of General Physiology, under Dr. J. H. Northrop, which has devoted itself to investigations of the nature of enzymes and other biologically active proteins of animal origin.

The world-wide reputation of the Princeton Laboratories was based in part on the isolation of a large number of crystalline enzymes and their precursors in Dr. Northrop's laboratory, and on Dr. W. M. Stanley's isolation of the tobacco mosaic virus and succeeding studies in the Department of Plant Pathology. Although the first isolation of a crystalline enzyme was achieved by Sumner in 1926, it is not too much to say that the work of Northrop and his 
colleagues, leading to the purification and crystallization of a long series of enzymes and related substances, has done more than that of any other group to open up the chemistry of enzymes; while, as is well known, Dr. Stanley's work decisively initiated the modern studies of virus particles. Numerous discoveries in animal pathology were also made within the laboratories, for example, Shope's rabbit papilloma, and many others, which the writer regrets he is unable to describe adequately.

It is most regrettable that the staff and equip. ment by which such results have been achieved should be dispersed. The main reason for the decision is apparently the contraction of the funds available and also a desire to concentrate the available resources on the Hospital and its auxiliary laboratories. It is understood that attempts made to enlist sufficient financial assistance to make possible the continuation of the Laboratories as a scientific unit were unsuccessful. Many of the younger members of the staff and some senior ones have already accepted posts elsewhere.

The result is the dispersion of a most valuable scientific establishment, which made a contribution to biological and medical research of unique importance. Situated a few miles from the university town of Princeton and within easy reach of New York, it was an ideal site for scientific work. The many British workers who enjoyed its hospitality will remember the efficient organisation of its wellequipped Laboratories and the friendly and agreeable atmosphere of its club-house, and will regret its passing acutely.

\section{RADIATIONS AND HEALTH}

$\mathrm{A}$

DOSE of radiation above the accepted tolerance limit of $0 \cdot 5-1$ roentgen per week presents hazards to the individual, notably those of sterility and cancer, and to his progeny-in the form of recessive mutations. The importance of the former effects has been recognized since the beginning of the century mainly as a result of the all too obvious injury to many of the early workers with radium and X-rays. The medical profession is therefore fully alive to these dangers. On the other hand, whereas the practitioner sees many examples of the effects of recessive mutations in man-the amaurotic familial idiot, the hæmophiliac, the alcaptonuric-he is seldom, if ever, able clearly to relate these to radiation effects. Thus the matter of genetic damage stands outside the field of practical medicine, and indeed so far has been largely a theoretical concern of eugenics.

Several new factors are at work which must ultimately alter this position. One is the recognition, now beyond dispute, that the genetic effects of radiation are cumulative. The increase in the mutation-rate is proportional to dose, no matter how long may be the period over which it is accumulated. It is estimated, for example, that a dose of $50 \mathrm{r}$. doubles the mutation-rate in man. It will be noted that the tolerance dose, if regularly received over a reproduction life-time, represents approximately $750 \mathrm{r}$. Jt is in no sense a threshold value, and finds general acceptance only on the understanding that not more than 1 per cent of the population receives it regularly. In these circumstances the genetic effects are reckoned to be not more serious than other inevitable ones. The same effects would be produced by a dose of $75 \mathrm{r}$. incident on 10 per cent of the population. Another factor is a fuller realization of the high levels of radiation to which the population is being subjected as a result of the increasing popularity of $X$-rays and radium in a wide variety of uses. Espec. cially is this true of the diagnostic and therapeutio uses. At one extreme, doses of the order of 10,000 r. are given in the deep X-ray treatment of malignancy, fortunately to sterile patients, and at the other a diagnostic screening after a barium meal accounts for 10-15 r. delivered directly to reproductive cells. Between the two stand a variety of conditions not in themselves fatal for which radiation is used; for example, ringworm and warts, and especially sterility in women, and on top of them come new treatments with radioactive isotopes. Finally, and most important of all, there stands in the background the sinister threat of an atomic war.

From the points of view of cancer and sterility, it is clearly in the interests of everyone to see that his accumulated radiation dosage both to tissue and reproductive cells is kept at the lowest possible level. He cannot know what the future has in store for him. From a national point of view, it is equally imperative that the level of peace-time radiation should be kept low. The people will be proportionately better able to tolerate the higher doses associated with preparation for, or the actuality of, an atomic war. The ultimate survival of a nation, if not indeed of the population of the world, may depend on just such a piece of elementary prudence as this. Peace-time levels cannot be ignored on the grounds that they are insignificant in relation to the radiation energy which may well be released in an atomic war. As Muller' has pointed out, much of the latter will not reach humans at all, and of the propor. tion which does, most of it will kill outright or sterilize. The insidious danger to the survival of the population lies in the breeding residuum, which will contribute a large number of recessive mutations to future generations. If these are already dangerously undermined in their genetic material by a wanton peace-time use of radiation by their forbears, the results will be serious.

These considerations require as a very minimum that public and scientific attention should be directed to the field of radiations and health in the broadest sense. In some measure, with this end in view, the Radiology Section of the British Medical Association at its Cambridge meeting held a symposium on the therapeutic applications of radioactive isotopes. The physical basis of the subject was presented in an opening paper by Prof. O. Frisch (Cavendish Laboratory), who dealt in particular with the various nuclear reactions which lead to the production of radioactive isotopes. Dr. A. S. McFarlane (National Institute for Medical Research) followed with a review of recent tracer applications, emphasizing the opinion that greater ultimate advantage will probably accrue from biochemical applications with the discovery of precise metabolic pathways in view, rather than from the more spectacular non-specific uses, as, for example, to measure blood-cell volumes or thyroid function.

The main contribution came from Prof. J. S. Mitchell, occupant of the newly created chair of radiotherapeutics in Cambridge. From his wide review covering all isotopes used therapeutically by external and internal administration, it is perhaps justifiable to refer in particular to his statements in relation to sodium-24, phosphorus-32, and iodine-131. These isotopes are usually administered internally, 